\title{
Entrepreneurship Education: Challenges and Strategies towards Promoting Entrepreneurship in Higher Education in Nigeria
}

\author{
Rowell Ubogu \\ Institute of Education, \\ Delta State University, \\ Abraka, Nigeria
}

DOI: https://doi.org/10.36941/ajis-2020-oo91

\begin{abstract}
Entrepreneurship education has great success in the field of education. Its activity has increased significantly in the USA, Asian and European countries during the last decades. Nevertheless, the training programme in developing countries like Nigeria has concentrated more on teaching knowledge and skills basically in principle. Products of these training are expected to be engaged in either self-employment or being employed. Unfortunately, the Niger-delta region of Nigeria is characterized by high levels of youth restiveness, unemployment, poverty and crime. Attempting to solve these ill, the questionnaire titled Entrepreneurship Education and Students challenges (EESC) was used to gather data from eight hundred and sixty-four students sampled from faculty of education and social sciences in Niger-delta region universities of Nigeria. The study identified various challenges, prospects and government efforts aimed at building the entrepreneurship culture among undergraduate students of Nigerian Universities especially graduates of the Niger-delta region. The study concluded by postulating certain recommendations which if adopted will drastically reduce the social vices faced in this region.
\end{abstract}

Keywords: Entrepreneurship; Education; Challenges of Entrepreneurship; Prospects of the Entrepreneur; Niger Delta Region

\section{Introduction}

Entrepreneurship was not valued until the early 1970s. It is now being regarded as an important field of study, having been integrated into the school curriculum, incorporating the best teaching practices offered at the top universities, such as Harvard. In the past, the field of entrepreneurship was thought to be little more than an applied trade as opposed to an academic area of study, which warrants research focus (Kuratko, 2014).

Since its inception, the central issue detracting from the improvement in entrepreneurship studies is the popular notion that entrepreneurship is a discipline with innate abilities. Such a notion has, however, been disregarded due to the different entrepreneurship courses that have emerged. Through a complete educational infrastructure, comprising over 1000 centres, more than 44 academic journals dedicated to entrepreneurship, more than 400 endowed professorships and chairs in entrepreneurship, and several professional associations, the growth of entrepreneurship education and scholarly research has increased significantly. Studies by Venter, urban, Beder, Oosthunzizen, Reddy and Venter (2015) has shown that entrepreneurial education is one of the fastest-growing 
disciplines in globally. This has led to its representation in institutions of higher learning.

Today, higher education institutions are responsible for the construction of a knowledge economy and society in all nations yet higher education in Nigeria has continued to battle with some challenges emanating from her policy on education which lither to did not agree with the development of skills for self-reliance. Higher educational institutions have continued to produce graduates who roam about without jobs and equally lack skills for self-reliance (Ezeugbor, 2010).

Despite the government's effort at job creation, there seems to be no headway to solving the employment problem among graduates in Nigeria. Most graduates in the country roam the streets in search of jobs with little or no success, regardless of policy programmes such as National Directorate of Employment (NDE) and others (Babalola, 2007; Igbatigbi, 2007). Entrepreneurship education, therefore, seems to be a solution. However, this necessitated the federal government in 2006 to give a directive to Nigeria Higher Education Institutions (HEIs) to include Entrepreneurship Education (EEd) as a mandatory course for all the students.

It has become necessary to train students of Economics on entrepreneurial skills especially in this era of the digital economy. The digital economy could be considered as an economic structure (Hamida, Taiba, \& Embonga, 2017). The digital economy affects the poverty rate dramatically by reducing the knowledge asymmetry of people, their socio-economic status notwithstanding. It has also increased the productivity level of the young female workforce. Individuals with digital technological skills have opportunities of getting employed in technology-driven sectors. Hence, entrepreneurship education has been identified as the major determinant of job creation (World Bank Group, 2016).

A recent study discovered many good reasons for introducing entrepreneurial education into universities and Higher Education Institutions (HEI), particularly African Tertiary Institutions. Some of these reasons as summarized by Bewauah, Buame and Hinson (2006) include:

- Graduate unemployment

- A paradigm shift from being an employee to becoming an employer

- Entrepreneurs as drivers of the engine of growth, the private sector

The curriculum of tertiary education in Nigeria, for a long time, has been criticized for its insensitivity to the dynamic experiences and contemporary life of the society. Poverty, unemployment, change of jobs and loss of employment has become a common occurrence. Nigeria inherited its educational system from the colonial government which prepares students strictly for employment. Securing a government or private sector paid employment remains an index of measuring success.

According to the National Bureau of Statistics report (2019), the state's unemployment rate indicates that 20.9million Nigerians are unemployed as in the third quarter of 2018, Akwa Ibom recorded the highest unemployment rate of $37.7 \%$ in the third quarter in 2018 . The unemployment rate also surges in other Niger Delta oil-producing states, despite the rise in monthly allocation to all tiers of government. The unemployment problem in Nigeria varies by regions. While the South-West looks to be the hotbed of job creation, other parts of Southern Nigeria like the Niger Delta Region are lagging. It is hard to disassociate this reality from the perpetual state of political and social unrest.

However, the neglect of this region invites economic crisis and its concomitants poverty and unemployment. Thus, for a nation/region to advance and witness development, it must offer the right value and education to grow young people into a sound and effective citizen and fully integrate the young people into the society (Ogudo, 2010).

Yet, in all developed economies, education for self-reliance has taken the centre stage and is recognized as the driver of economic growth and competitiveness in the labour market (European Commission, 2004). The success of a nation's economy depends solely on the quality of graduates which the educational system provides. There is, therefore, the need to equip citizens with life skills that will enable them to contribute productively to their personal, family lives and the society at large (Aliyu, 2007). The objective of this paper, therefore, is to present a case of a concise review of student 
entrepreneurship exploration in Higher Education as a mechanism to creating sustainable employment and to introduce skills of entrepreneurship to students in the Niger Delta region of Nigeria. To reduce the high unemployment rate, poverty and youth restiveness in the region. Specifically, the paper intends to identify, analyse relevant literature relating to this study that researchers have not attempted to carry out in this region by defining and providing realities, challenges and the development agenda of student entrepreneurship in higher institutions in Niger Delta Region of Nigerian. Thus this paper examines the entrepreneurship education; challenges and strategies towards promoting entrepreneurship in higher education in Nigeria.

Although there is no generally accepted definition of entrepreneurship in the literature (Carlock,1994; Grant \& Perren, 2002; Venter, et al.,2015); despite the difference in the definitions, similarities do arise concerning the terms used such as innovation, value creation, creative process, risk-taking and resourcefulness process (Fiet, 2000). However, the definition should be given to address the issues at hand. In the Schumpeter definition, for example, entrepreneurship has identified and turned new economic ideas into opportunities (Bruyat \& Julien, 200o) Thus, the entrepreneur is an individual who creates opportunities out of challenges (Boltman \& Thompson, 2004).

Similarly, Hisrich, Peters and Shepherd (2010) defined an entrepreneur as a dynamic process of creating incremental wealth. It involves an individual who is willing to take risky ventures and who uses his/her initiative to manage resources for optimal productivity. Also, it entails empowering oneself with knowledge of developing legacy to his business for generations to come.

Osuafor, Okeke and Nnorom (2010) defined entrepreneurial education as a systematic training given to individuals to equip them life skills that will enable to make a meaningful impact in their life and contribute positively to the society. Due to the global economic downturn, especially in third world countries, the role of entrepreneurship education cannot be overemphasized. It on this basis that major developmental discourse focus on the provision of entrepreneurship education to the youths.

Nigeria, like any other country of the world, had her early entrepreneurial and business class men. These two classes, however, have not evolved much as would be expected. This lack of development was not due to the British colonial rule in Nigeria. As stated by Aladekomo (2004), the history of Nigerian educational policy could be traced back to the colonial period. The colonial administrators adopted the British form of education. The educational policy was therefore aimed at providing the colonial masters with well-equipped manpower to aid effective administration of the country. The aims and objectives of education in Nigeria then was to produce graduates who will be able to read and write to be able to take on such roles as clerks, interpreters and inspectors, with little or no entrepreneurial skill for self-sustenance or even establish and manage their own business (Anachuna, 2013; Igbongide, 2015; Kpee \& Nwikina, 2011).

Later in the mid-'7os, the Nigerian government established some small and medium industries to boost entrepreneurship activities in the country. Some of the institutions established to boost entrepreneurship include the Nigerian Bank for Commerce and Industry (NBCI), Nigerian Agricultural and Co-operative Bank (NACB) and Small and Medium Enterprise Development Agency of Nigeria (SMEDAN). Federal Government's initial response towards boosting entrepreneurship activities and addressing these problems of unemployment and poverty was from the output end. However, these initiatives only achieved very minimal successes (Okojie, 2008; Osibanjo, 2006). Hence, in higher institutions, Nigerian undergraduates, through Entrepreneurship Education are offered opportunities to respond to social challenges by identifying goods or services of commercial value needed to bring their solution.

Entrepreneurship education should be regarded as a critical component of our educational curriculum because of the obvious needs to generate alternative sources of employment. The Nigerian graduates of the $21^{\text {st }}$ century cannot afford to be a "jack of all trade and master of none" if he has to be employable, he has to go to the labour market with a specialized skill. Section one of the National policy on education (Federal Republic of Nigeria FRN, 2004) emphasized the need for 
functional education to be relevant, practical and comprehensive. Also, emphasis should be given to the acquisition of suitable entrepreneurial skills and competences for the development of the individual and society. This implies that the quality of instruction at all levels has to be directed towards including the values and competencies necessary for self - reliance.

Akpotu and Agabi (2011) urged higher institutions in Nigeria to integrate entrepreneurship education into their curriculum such that it will be made compulsory for all categories of students, notwithstanding their area of specialisation. This is in line with the presidential directive for the inclusion of compulsory entrepreneurship education in higher education curriculum, having realised the importance of cultivating such skills in the citizenry for job creation. It would require universities and tertiary institutions in the country to begin to build an entrepreneurial human capital base for national development. In the same view, Abubakar (2010) illustrated this policy decision in the form of a conceptual model of entrepreneurship education. As shown in figure 1 below:

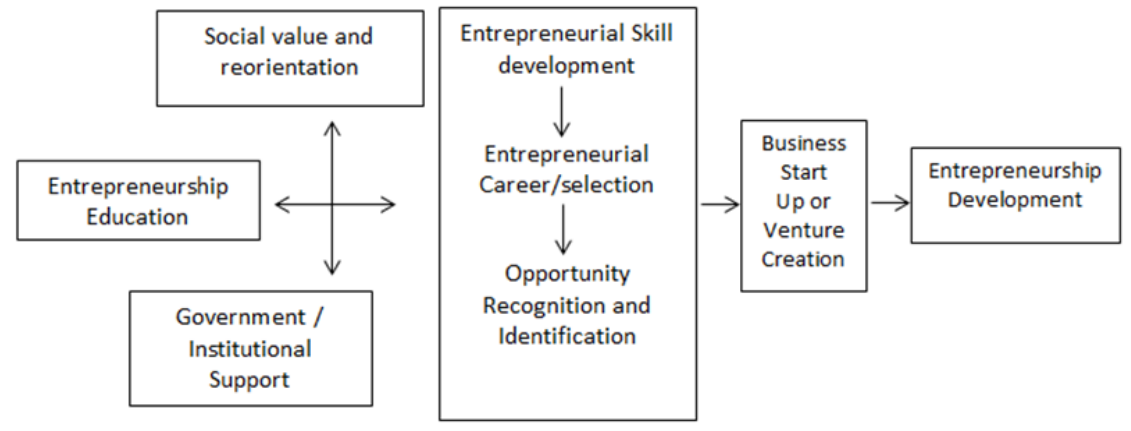

Figure 1: Conceptual Model of Entrepreneurship Education

Source: Abubakar, 2010: P 146

This model tries to identify them to integrate entrepreneurial education to alleviate the persistent socio-economic problem particularly youth unemployment and high rate of poverty in the country. Students will be equipped with the skills needed to explore areas of opportunities for job creation (Ayomike, 2013).

Equipping students with the right skills remain one of the major challenges of entrepreneurship education. This is why most students still lack the needed entrepreneurial skills, even when they have a strong drive to becoming entrepreneurs. Despite the problems militating against entrepreneurship education, better prospects await entrepreneurial graduates. These include the development of entrepreneurs by skills in the learning process (Ncanywa, 2019; Osibanjo 2006). Thus, emphasis on the discovery facts and explaining the facts are then applied to life situations through the use of these skills.

Today unemployment among graduate from the Nigeria educational system has become a national problem. Kiadese and Kayode (2010) posited that the federal governments of Nigeria and other stakeholders in education have come to realize the rationale and the need for the integration of Entrepreneurship Education in the school curriculum. To achieve this, Entrepreneurship Education has been integrated into Secondary, Polytechnic, Teacher Education and University Curriculum in Nigeria. Centres for Entrepreneurship education have been established by the federal government in some states of the federation. Some philanthropists have also established a few centres for entrepreneurship education, for instance, the Chike Okoli Centre for Entrepreneurship Education at the Nnamdi Azikiwe University, Awka in Anambra State. Presently, Delta State University, Abraka has introduced entrepreneurship education courses in all level of studies. These efforts are welcomed developments; nevertheless, a lot still needs to be done to promote Entrepreneurship Education in Nigeria. 


\section{$1.1 \quad$ Theoretical Framework}

The theoretical framework of this work is focused on Liberal Education School of thought propounded by the Association of American Colleges and Universities (AAC\&U). The body holds the view that everybody must have functional education through the acquisition of life skills to reduce hardship. Entrepreneurship education opens the door for individuals to acquire practical skill for selfreliance and national development.

Wealth creation for both individuals and government will be better achieved through entrepreneurship education. Operationally, therefore, entrepreneurship can be defined as an individual's ability to acquire life skills to enable him or her effectively explore areas of investment opportunities. The role of entrepreneurship in economic growth and development and job creation cannot be over-emphasized. To help promote entrepreneurship, there is the need to restructure the educational curricular to incorporate entrepreneurship education. This is because its education system must be considered as the foundation and necessary element for every nation to promote economic growth and development.

\subsection{Purpose of the Study}

The purpose of the study therefore includes;

1. Appraise the challenges militating against entrepreneurship education in Universities in the Niger-delta region of Nigeria.

2. Evaluate the prospects of entrepreneurship education for students of Nigerian Universities upon graduation

3. Enact measures to enhance the knowledge of entrepreneurship among undergraduate students in Nigerian Universities

\subsection{Research Questions}

The study was guided by the following research questions;

1. What are the challenges acting against entrepreneurship education in Universities in the Niger-delta region of Nigeria?

2. What are the prospects of entrepreneurship education for University students upon graduation?

3. What measures has the government taken to enhance the knowledge of entrepreneurship among undergraduates in Niger-delta Universities?

\section{Methods}

\subsection{Sample and Participant Selection}

The data for the study was generated from a sample of 864 graduating students randomly selected from a population of 1854 students from the faculties of education and social sciences of universities in the Niger-Delta Region of Nigeria.

\subsection{Assessment and Measures}

A twenty-four item questionnaire labelled entrepreneurship education and students challenges (EESC) was used to depict the information used for the study. Two Measurement and Evaluation experts validated the instrument. The reliability of the instrument was established using the Cronbach alpha-generating a coefficient of 0.79 , indicating that the instrument was reliable. The EESC was designed to obtain the opinions of respondents in a 4-point Likert scale manner of Strongly 
Agree, Agree, Disagree and Strongly Disagree.

\subsection{Procedure}

The study adopted a descriptive survey technique. The opinion poll was conducted solely by the researcher and only 822 of the EESC forms were returned in good and usable condition.

\subsection{Statistical Analysis}

The frequency distribution and descriptive statistics obtained were analysed with the SPSS software version 22, while a mean score below 2.50 was interpreted as negative (disagreeing to the research question) and a mean score above 2.50 was interpreted as positive (agreeing to the research question).

\section{Results}

Respondent's opinions regarding research question one: the challenges acting against entrepreneurship education in Nigerian Universities.

Table 1: Weighted mean score of respondent's opinions

\begin{tabular}{clcc}
\hline S/No & Challenges & Mean & Decision \\
\hline 1. & Quick fix approach to entrepreneurship education & 2.86 & Agree \\
2. & Poor concept of entrepreneurship & 2.74 & Agree \\
3. & Absent of competent lecturers & 2.63 & Agree \\
4. & Inadequate facilities at entrepreneurship centres. & 2.56 & Agree \\
5. & Absent of entrepreneurship centres. & 1.98 & Disagree \\
6. & Lack of funds & 2.62 & Agree \\
7. & Poor recognition of certificate issued from apprenticeship training scheme. & 2.88 & Agree \\
8. & Stereotype pattern of educational curriculum favouring the acquisition of & 2.90 & Agree \\
& knowledge without practical application of the concept. & & \\
\hline
\end{tabular}

Depicted in Table 1, are the mean scores of 2.86, 2.74, 2.63, 2.56, 2.62, 2.88, and 2.90 all indicating a positive response that quick-fix approach, the poor concept of entrepreneurship absent of competent lecturers to handle entrepreneurial courses, lack of inadequate training facilities, lack of funds hinders entrepreneurship education and development, Poor recognition of certificate issued from apprenticeship training scheme and stereotype pattern of the educational curriculum are all challenges acting against entrepreneurship education in higher institutions in Niger-Delta region of Nigeria. The low mean score of below 2.50 indicates that students hold contrary opinions to those factors as challenges facing entrepreneurship education in tertiary institutions in the Niger-Delta region of Nigeria. Thus, it can be concluded that the absence of entrepreneurship centres is not perceived as a challenge based on its mean score of 1.98 which falls below the average of 2.50 .

Respondent's opinions regarding research question two: the prospects of entrepreneurship education for students of Nigerian Universities upon graduation.

Table 2: Weighted mean score of respondent's opinions

\begin{tabular}{clcc}
\hline S/No & Prospects & Mean & Decision \\
\hline 1. & Reduction of societal miscreants. & 2.66 & Agree \\
2. & Creative and risk-taking skill is developed. & 2.84 & Agree \\
3. & Financial independence. & 2.71 & Agree \\
4. & The ability of students to be self-employed. & 2.93 & Agree \\
\hline
\end{tabular}




\begin{tabular}{clcc}
\hline S/No & Prospects & Mean & Decision \\
\hline 5. & Organize training based on entrepreneurial experience. & 2.65 & Agree \\
6. & Adequate knowledge of the course. & 2.04 & disagree \\
7. & Open workshops and be masters. & 3.02 & Agree \\
8. & Reduction of rural-urban migration. & 2.53 & Agree \\
\hline
\end{tabular}

Depicted in Table 2, are the mean scores of 2.06, 2.84, 2.71, 2.93, 2.65, 3.02, and 2.53 respectively indicate a positive response that Reduction of societal miscreants, Creative and risk-taking skill are developed, Financial independence, Ability of students to be self-employed, Organize training based on entrepreneurial experience, Open workshops and be masters and Reduction of the rural-urban migration are all prospects of entrepreneurship education for students of Nigerian Universities upon graduation, also responding negatively that adequate knowledge of the course is not perceived as a prospects based on its low mean score of 2.04 below the average mean of 2.50 .

Respondent's opinions regarding research question three: measures the government has taken to enhance the knowledge of entrepreneurship among undergraduate students in Nigerian Universities.

Table 3: Weighted mean score of respondent's opinions

\begin{tabular}{|c|c|c|c|}
\hline S/No & Measures & Mean & Decision \\
\hline 1. & Establishment of entrepreneurship schools and centres for skill acquisitions. & 2.51 & Agree \\
\hline 2. & $\begin{array}{l}\text { Developing a policy on entrepreneurship education in the National Policy on } \\
\text { Education. }\end{array}$ & 2.53 & Agree \\
\hline 3. & Providing soft loans for undergraduates to start their own business. & 1.86 & disagree \\
\hline 4. & Recognizing entrepreneurship education certificates from training centres. & 2.22 & disagree \\
\hline 5. & $\begin{array}{l}\text { Creating a well-structured curriculum for entrepreneurial programmes at all } \\
\text { levels of education }\end{array}$ & 2.48 & disagree \\
\hline 6. & Creation of mass entrepreneurial Sanitization programme. & 2.42 & disagree \\
\hline 7. & Inclusion of a carrier path for entrepreneurship programmes & 1.99 & disagree \\
\hline 8. & Equipping entrepreneurial centres with facilities and power to operate facilities. & 2.20 & disagree \\
\hline
\end{tabular}

From Table 3, the mean score of 2.51and 2.53 respectively indicates a positive response that establishment of entrepreneurship schools and centres for skill acquisitions and developing a policy on entrepreneurship education in the National Policy on Education has been seen to enhance the knowledge of entrepreneurship among undergraduate students in universities in Niger Delta Region. However, the low mean scores ranging from 1.86 to 2.48 respectively indicate areas where the options of the students indicate that government has not lived up to the challenge of enhancing entrepreneurship education among undergraduates of Nigeria universities in the Niger Delta Region.

\section{Discussion}

The outcome of this study divulges that regardless of the huge benefit accruing to being an entrepreneur, possible challenges face the Niger-Delta undergraduate students in their quest to attain or achieve entrepreneurship education. The study upholds that the quick fix approach to entrepreneurship education is a major challenge as Ubong (2017) points out that it appears the focus "of Entrepreneurial education in Nigerian higher education institutions" is either blurred or skewed towards private business development for internally generated revenue (IGR). Adding that what is required is a proper definition of philosophy and goals. Likewise, the study also holds that the undergraduate students in their determination to embrace the entrepreneurship education concept do face challenges despite the huge benefit derivable from being an entrepreneurial student. One of such challenges was earlier identified by Ronstadt (1990) as it relates to the definitional controversy and the reluctance to recognize entrepreneurship as an established discipline. 
Other studies (Ayafa, 1994; Gorman, Hanlon, \& King 1997) have shown that the belief and misconception that entrepreneurship education is reserved for dull students who never did well in school. They further maintained that such erroneous misconception has deprived gifted boys and girls who would have excelled in building entrepreneurship and tapping the benefits from embracing this all-important innovation in the education industry. The scepticism around entrepreneurship being an inherent trait (entrepreneurs are born not made) has increased the negative attitude towards the development of entrepreneurship pedagogy.

However, it was surprising that there were no competent lecturers to handle entrepreneurial courses in the Niger-Delta Region because educational institutions are ideal for the shaping of entrepreneurial cultures, equipping them for success in today's vigorous business environment. Entrepreneurship education and incubators, located on campuses are instrumental in developing student's desires and intentions to be entrepreneurial because individuals who are exposed to entrepreneurial skills are more likely to see career opportunities in entrepreneurship than those who are not exposed to it.

The pedagogical problem is that more systematic and psychologically focused entrepreneurial competencies are better favoured than the traditional approach. According to Taatila (2010), Entrepreneurial skills can be acquired through pragmatic development projects. Also, worth noting is the experience of entrepreneurship in Denmark. To take care of this challenge, The Danish Government introduced a program "strategy for education and training in entrepreneurship," which was established to equipped qualified managers on entrepreneurial skills. The focus of the programme was also on equipping the workforce with the necessary skills to function effectively in the job market (The Danish Foundation for Entrepreneurship - Young Enterprise, 2011).

Supporting the above findings, Ustyuzhina, Mikhaylova and Abdimomynova (2019) in their research on entrepreneurial competencies in higher education, 710 students of economies faculties took part in the research. It was also found that majority of the respondents did not have confidence in the competence of their teachers. This finding is worrisome as the task of the teacher goes beyond providing abstract training. He or she should also provide a conducive environment that will foster the learning of the students. Additionally, institutional aspects of promoting entrepreneurship by introducing short courses and using conventional teaching methods are lagging behind Qureshi \& Fawad, 2015, found positive correction between teachers' competencies are not matching with the international standard which is responsible in decline in the performance of students in the process of enhancing their theoretical and business knowledge and skill.

This study also held that inadequate facilities at entrepreneurial centres in the universities constituted a challenge to entrepreneurship education. Ementa (2013) upheld this finding where he discussed that entrepreneurship training in Nigeria is defective having no practical orientation. This according to him has made the products of entrepreneurship training perform below standard when given opportunities in the industry. Ementa (2013) confirmed this inadequacy of infrastructure when she stressed that there are inadequate infrastructures and equipment in existing entrepreneurship centres. According to her, a visit to most of our schools reveals a glaring picture of complete dilapidated classroom structures, laboratories and study equipment.

The study also revealed that a lack of funds hinders entrepreneurial education and development. This statement agrees with the views of Inegbenebor (2005); Azubike (2006); Hofer and Potter (2010). They posited that stimulation and sustenance of entrepreneurship education and development can be traced to carefully articulated government policies and funding. Also, the federal government provides grants to Universities, College of Education and Polytechnics through its various agencies such as National Universities Commission (NUC) and National Commission for Colleges of Education and Polytechnics (NCCE). Resources requirements for entrepreneurial education and development, however, are not adequately recognized in funding allocation mechanisms.

This situation differs in the case of the American higher education system where her policies of funding entrepreneurial education and development include using up sources of funding, improving 
the connection between universities and major entrepreneurs, traditions of philanthropy and opening up new disciplines to promote the acquisition of entrepreneurial skills. This is one of the major driving force of entrepreneurship education in Europe and Asia continents (Solomon, Ramari \& Alabduljader, 2018).

Also, the study reveals poor recognition of certificate issued from apprenticeship training scheme. This will potentially lead to poor societal recognition of entrepreneurs. Thus, students prefer to become job seekers in a prestigious company then become a job creator. Compared to Malaysia $(77 \%)$ and Thailand $(76 \%)$ the status as entrepreneurs is seen below $(55 \%)$. While, limitations of job opportunities will potentially lead to the inability of the labour market to absorb educated works that continues to accumulate (Ghina, 2013).

Furthermore, some of the above findings are released in the work of Ghina (2013) that the curriculum within universities in Indonesia does not have a standard, lack of lecturer skills to provide a new paradigm on the importance of entrepreneurship, entrepreneurship centres within higher education institution are not operating effectively, lack of cooperation between formal education with business owners and community, cooperation with financial and non-financial institutions are still limited.

Although, the analysis reveals that students do not agree with a statement relating to absent of entrepreneurship centres in the Niger Delta Regions but there is still pressing need for government to live up to its expectation by equipping centres built for entrepreneurship and making such centres functional as to attain the aim behind establishing them. Such centres should be innovative and may also extend entrepreneurial services by providing short courses to communities such as Technical and Vocational Education and Training (TVET) colleges and unemployed people generally targeting rural and urban communities (Ncanywa, 2019).

This study also identified numerous prospects for the undergraduate's students who embrace entrepreneurship education. One of such prospects is the reduction of societal miscreants. When entrepreneurship education is given to the students through workshops and seminars, they will be readily equipped with the relevant skills needed for employability and job creation. Finally, governments in collaboration with oil and gas multinational may set up centres for entrepreneurship and support vulnerable young people in short or long term courses or training to develop appropriate entrepreneurship skills and expertise to make them employable (Aneozeng, Usang, Amimi \& Ndifor 2011).

This study also established that entrepreneur training equips the undergraduates with boldness to venture into risk-taking and creativity as he sets up his own business. These findings are corroborated by the views of other researchers (Dhliwayo 2008; Kpee \& Nwikina 2011; Ustyuzhina et al., 2019).

However, it is noted that only the students with the "right entrepreneurial attitude" that is creative and has a risk taken attitude will successfully process or graduate into an entrepreneur. The major theme in entrepreneurship education is risk and how entrepreneurs are inclined towards risky alternatives or how they should manage risk in the course of being innovative or creative (Busenitz, 1999). The study also established that entrepreneurship education graduate on completion of his training can open workshops where he earns his living and also become an employer of labour as he trains and equips his apprentice with knowledge and skills.

However, the students disagreed that they usually received adequate knowledge of entrepreneurial training. Several studies have indicated that university-based entrepreneurship education aims at infusing the entrepreneurial culture and spirit of the students; developing new skilled entrepreneurs and new businesses based on science and technology. In other words, the outcome is that well-educated entrepreneurs create jobs. But entrepreneurial training is still ineffective because of a series of challenges facing entrepreneurship education (Ghina, 2013; Mitehelmore \& Roweley, 2010). According to Oosterbeek, et al. (2010) and Xianming (2013), the entrepreneurship programmes of most higher institutions do not provide adequate real-life skills that will enable the students to become useful members of the society because such programmes often fail 
to provide the students with enough opportunities for self-development. However, other authors, such as Packham, Jones, Miller Picknell and Thomes (2010); Mueller (2011) have a different opinion than students increase in knowledge in entrepreneurship education in terms of skills, know-how and better entrepreneurial attitude.

This study also identified two major efforts the governments have put in place to encourage entrepreneurship education among undergraduates in the Niger Delta region of Nigeria. Such efforts include establishing entrepreneurship schools and centres for skill acquisitions and also has made provision for entrepreneurship education through the National Policy on Education (Kpee \& Nwikina, 2011, Okubotomibi, 2011, Delta State Government, 2019;). The efforts of the Delta State Government also confirmed the student's assertion. According to Delta State Government (2019), "there is a progressive change, among unemployed youths, from government (Salaried) employment to private sector entrepreneurship based self-employment. Delta Youths are now imbibing the notion of finding gainful employment outside, government or public service". This is made possible through government partnership and collaboration with private sector training centres.

The above are some efforts the government has used to ensure the development of the entrepreneurship mindset but despite all these efforts, embracing and practising the entrepreneurial skill is still low among Nigerian graduates. This low status is further revealed by the findings of this study as the students disagreed to the fact that government efforts to enhance entrepreneurship in areas like providing soft loans, recognizing entrepreneurship education certificate from training centres, creating a well-structured curriculum for entrepreneurship programmes are not yet achieved. This is in line with Kpee \& Nwikina (2011), that the efforts made toward entrepreneurial culture and self-employment have resulted in various activities such as the Delta State job creation scheme that has empowered over 4,200 youths (Delta State Government, 2019). This may be the reason why most of the graduates opted for a career in entrepreneurship (Ordu \& Abdulkarian, 2018; Seikkula-Leino, 2011). However, the problem is that these actions do not always have the desired result (Kuratko, 2005).

\section{Conclusion and Recommendations}

The paper aimed to explore how entrepreneurship education in universities in the Niger Delta Region of Nigeria can be used as a development tool to reduce youth and graduate unemployment. Thus, attainment of a level of optimum employment is a life wire of any economy which should also aim at sustaining growth and development as it will take care of some, if not all other social ills like poverty, armed robbery, kidnapping and prostitution (Anachuna, 2013).

However, entrepreneurship education is a novel child recently enforced into the Nigerian higher educational system. It is a visible and empiric phenomenon that has gained a lot of scientific interest. Lots of efforts have been made by both the privates and public sectors such as the building of entrepreneurship centres in universities, introducing the entrepreneurship education across all levels of university education, establishing job creation office at various states etc., however, these actions have not yielded meaning results to curb the youth restiveness in this Niger Delta region of Nigeria. There have been many reported cases of hundreds of unemployed university graduates embarking on demonstrations at strategic places in the country to express their concern.

In this note, it can be seen that Niger Delta Region need graduates that can possess entrepreneurship traits. This could be realized through the education system by providing entrepreneurial education that can drive to economic development. It is recommended that universities need to contribute to the development of entrepreneurs by providing entrepreneurship skills in the learning process. This could be achieved by engaging in several activities such as:

1. Engage in entrepreneurship advocacy, campaigns and enlightenments programmes to provide information about entrepreneurship and encourage students to consider entrepreneurship as a career.

2. Establishing job creation offices in each of the states in the Niger Delta Region of Nigeria. 
Such as the one established by Delta State government where over four thousand two hundred $(4,200)$ youths have been trained and established.

3. Allow university governance to create centres of entrepreneurship and innovation, equip these centres and even extend the service by providing short courses to youths in collaboration with the job creation offices in various Regions in Niger Delta.

4. Employing skilled professionals in entrepreneurship in the universities to run workshops and seminars on apprenticeship concept (like the entrepreneurs' centre of Delta State University, Abraka).

\section{References}

Abubakar, S.G. (2010). Refocusing education system towards entrepreneurship development in Nigeria: a tool for poverty eradication. European Journal of Social Science, 15(1), 140-150.

Akpotu, N. E., \& Agabi, O. G. (2011). Education and Training for Entrepreneurship: A Synergy between Tertiary and Non-Formal Educational Institutions in Nigeria. Education and Training for Entrepreneurship Book of Reading: National Association of Educational Administration and Planning (NAEAP).

Aladekomo, F.O. (2004). Nigeria Education Policy and Entrepreneurship. Journal of Social Science, 9(2), 75-84.

Aliyu, M. (2007). Perception of the State of Technical Teachers in Nigeria. Multidisciplinary Journal of Research Development 9 (1). Retrieved from http://www.google.com

Anachuna, O., N. (2013) Reorienting Nigeria Education System Toward Entrepreneurship Development Programme: A strategy for curbing unemployment among youths. Unizik Orient Journal of Education, 1, 120127.

Aneozeng E. A., Usang, E., Amimi, P.B., \& Ndifon, E.O. (2011). Entrepreneurship Empowerment and Gainful Employment: Panacea for Youth Restiveness in the Niger Delta Region of Nigeria. An International MultiDisciplinary Journal, 5(1), 107-118.

Ayafa, M.C. (1994). State of Technical Education in Nigeria. Journal of Technical Teachers' Education, 1(2),

Ayomike, C. S. (2013). Entrepreneurial skills in Rooting for Entrepreneurship Development of Building construction Graduates of Technical Colleges in Delta State. Unizik Oriet Journal Education, 7(1), 65-74.

Azubuike, R. (2006). Challenges and implication of entrepreneurial development of business education in tertiary institutions. Business Education Journals, 5(2), 49-58.

Babalola, J.B. (2007).Reinventing Nigerian higher education for youth employment in a competitive global economy. A distinguished lecture delivered at the University of Calabar. Department of Educational Administration and Planning, University of Calabar.

Bewauah, K., Buame, S., \& Hinson, R. (2006). Reflections on entrepreneurship educations in African tertiary institutions. Acta Commercial, 1-9.

Boltman, B \& Thompson, J. (2004). Entrepreneurs, Talent, Temperament, Technique, $2^{\text {nd }}$ Edition. UK: Elsevier Butterworth-Heinemann.

Bruyat, C., \& Julien, P. A. (200o). Defining the field of research in entrepreneurship. Journal of Business Venturing, $16(2), 165-180$.

Busenitz, LW. (1999). Entrepreneurial risk and strategic decision making: It's a matter of perspective. The Journal of Applied Behavioural Science, 35(3), 325-340.

Carlock, R. (1994). The need for organization development in successful entrepreneurial firms. New York: Garland Publishing, Inc.

Cooney, T. (2012). Entrepreneurship skills for growth-orientated business. OECD, 1-7.

Crum, M., \& Chen, Y. (2015). Self-employment and subjective well-being: A multi-country analysis. International Journal of Entrepreneurship, 19(1), 15-25.

Delta State Government (2019). Job and Wealth Creation Scheme. Documentation and Public Affairs Unit. Info@deltastatejobcreation.ng

Dhliwayo, S. (2008). Experiential Learning in entrepreneur Education: a Prospective Model for South African Tertiary Institutions. Education and Training, 50 (4), 329-332.

Drucker, P.F. (2006). Innovation and entrepreneurship. New York: Harper \& Row.

Ementa, C. N. (2013). Curriculum Implements of Entrepreneurial subjects at the Senior Secondary School: A case for Entrepreneurship Education at the Senior Secondary School in Nigeria Unizik Orient Journal of Education, 7(1), 165-17.

Entrepreneurship in American Higher Education. (2006) A report from the Kauffman panel on entrepreneurship curriculum in higher education. 
European Commission (2004). DG Enterprise 2004 Annual Management plan, Bruxelles.

Federal Republic of Nigeria (2004). National policy on education. Yaba Lagos: NERDC Press.

Ezeugbor, C. O. (2010). Higher Education Policy and Entrepreneurship Education in Nigeria. Unizik Orient Journal $5(1)$.

Fiet, J. O. (200o). The pedagogical side of entrepreneurship theory. Journal of Business Venturing, 16, $101-117$.

Ghina A. (2013). The Effectiveness of entrepreneurship education in higher institutions. Journal of social and Behavioural Sciences, 155(2014), 332-345.

Gorman, G., Hanlon, D., \& King, W. (1997). Some research perspectives on entrepreneurship education, enterprise education and education for small business management: a ten-year literature review. International Small Business Journal, 15(3), 56-77.

Grant, P; \& Perrin, L. (2002). Small business and entrepreneurial research: Meta-theories, Paradigms and Prejudices, International Small Business Journals, 20(2), 185-211.

Hamida, N.A., Taiba, H., \& Embonga, F. (2017). The effect of the digital economy on students' entrepreneurial characteristics and entrepreneurship as career choices: A comparative study.4 ${ }^{\text {th }}$ International Conference on Electronic Commerce (ICEC), 154 .

Henry, C. (2007). Entrepreneur in the creative industries: An international perspective. Edward: Elgar Publishing.

Hisrich, R. D., Peters, M. P.,\& Shepherd, A. (2010).Entrepreneurship, $8^{\text {th }}$ Edition. New York: McGraw-Hill.

Hofer, A.R., \& Potter, J. (2010). University entrepreneurship support: Policy Issues, Good Practices and Recommendations. A note prepared for the directing committee of the local economy and employment programme of the OECD.

Igbatigbi, F.A.(2007). Level of Awareness in Entrepreneurial Development among the students of Tertiary institutions in Nigeria. International Journal of Research in Education, 4(1\&2),296-304.

Igbongidi, B. P. (2015). Entrepreneurship Development Entrepreneurship: Theory and Practice. Magill Publishing House.

Inegbenebor, A.U (2005). Education for Entrepreneur: Experience at the University of Benin. Paper presented at the Inaugural Conference of the Academy of Management, Nigeria held at Abuja on November $22^{\text {nd }}$ and $23^{\text {rd }}$, 2005 .

Kpee, G. G., \& Nwikina, L. (2011). Entrepreneurship education and reforms: Challenges and prospects for undergraduate students in Nigerian Universities.Nigerian Journal of Educational Research and Evaluation, $10(2)$

Kuratko, D. (2005). The emergence of entrepreneurship education: Development, trends and challenges. Entrepreneurship Theory and Practice, 29(5), 577-597.

Kuratko, D. F. (2014). Introduction to entrepreneurship, $9^{\text {th }}$ edition. Canada: South-Western Cengage Learning.

Mitchelmore, S., \& Rowley, J. (2010). Entrepreneurial competencies: A literature review and development agenda. International Journal of Entrepreneurial BehaviourE Research, 16(2), 92-111.

Mueller, S. (2011). Increasing entrepreneurial intention: Effective entrepreneurship course characteristics. International Journal of Entrepreneurship and Small Business, 13 (1), 55-74.

National Bureau of Statistics report (2019). National Bureau of Statistics. Retrieved from http//www.google.com/tradingeconomics.

Ncanywa, T. (2018). Entrepreneurship and Development Agenda: A case of Higher Education in South Africa. Journal of Entrepreneurship Education 22(1).

Ogudo, P.A. (2010). Role of Parent in the Empowerment of Youths Through Entrepreneurial Education. Journal of Teachers Perspective (JOTEP). A Publication of Association of Nigeria Teachers (ASSONT).

Okojie J. A. (2008). Policy framework and strategy for entrepreneurship development for Nigeria universities. A paper presented at the national sensitization workshop on entrepreneurship development in Nigerian universities organization by the National Universities Commission, Abuja, 21 May.

Okubotomibi, J. E. (2011). Education and Training for Education and Training for Entrepreneurship. National Association of Educational Administration and Planning (NAEAP) Book of Reading. Delta State University Press: Abraka.

Oosterbeek, H., Van Praag, M., \& Ijsselstein, A. (2010). The impact of entrepreneurship education on skills and motivation. European Economic Review, 54(3), 442-454.

Ordu, P., \& Abdulkarim, M. (2018). Effect of new entrepreneurial learning approaches in the development of entrepreneurial skill by colleges of education students. Nigeria Journal of Business Education, 3(2), $122-132$.

Osibanjo, O. (2006). Concept of entrepreneurship. A paper presented at the Workshop on Entrepreneurship and Innovation for 200 level students of University of Ibadan, Jan. 18.

Osuafor, A.M., Okeke, S.O. \& Nnorom, N.R. (2010).Strategic for challenges to Entrepreneurship Education in Science for Sustainable Development. Unizik Orient Journal of Education, (5), 30-37. 
Packham, G., Jones, P., Miller, C., Pickernell, D., \& Thomas, B. (2010). Attitudes towards entrepreneurship education: A comparative analysis. Education and Training, 52(8-9), 568-586.

Qureshi, S., \& Fawad, S. (2015). An exploratory study of entrepreneurial centres in Pakistan: An untapped market opportunity.

Ronstadt, R. (1990). Emerging structures in entrepreneurship education: Curricular designs and strategies. Entrepreneurship Theory and Practice, 55-70, 58.

Sardeshmukh, S. R., \& Smith-Nelson. R. (2011). Educating for an entrepreneurial career: Developing opportunity recognition ability. Australian Journal of Career Development, 20(3), 47-55.

Seikkula-Leino, J. (2011). The implementation of entrepreneurship education through curriculum reform in Finnish comprehensive schools. Journal of Curriculum Studies, 43(1), 69-85.

Solomon, G., Ramani, R., \& Alabduljader. (2018). The U.S. approaches entrepreneur education. International Enterprise Education, 15-17.

Taatila, V.P. (2010). Learning entrepreneurship in higher education. Education and Training, 52(1), 48-61.

The Danish Foundation for Entrepreneurship - Young Enterprise (2011). Impact of Entrepreneurship Education in Denmark-2011. Ejlskovsgade.

The Danish Government. (2013). Denmark-a nation of solutions. Enhanced cooperation and improved frameworks for innovation in enterprises.

Ubong, B. (2017). Entrepreneurship education in Nigeria: Issues, challenges, and strategies.Nigerian Journal of Business Education (NIGJBED), 4(1),

Ustyuzhina, Mikhaylova and Abdimomynova, A. (2019). Entrepreneurial Competencies in Higher Education. Journal of Entrepreneurship Education 22(1).

Venter, R., Urban, B., Beder, L., Oosthuizen, C., Reddy, C., \& Venter, E. (2015). Entrepreneurship: Theory in practice. London: Oxford University Press.

World Bank Group (2016) Increasing entrepreneurship in the digital economy, trade and competitiveness global practice. 11-14.

Xianming, W. (2013). Reflection on challenges and countermeasure of entrepreneurship education in China. Cross-Cultural Communication, 9(2), 18-22. 